\title{
Rereading a tree-ring database to illustrate depositional histories of subfossil trees
}

\author{
Samuli Helama, Tomi P. Luoto, Liisa Nevalainen, and Johannes Edvardsson
}

\begin{abstract}
Late Quaternary tree-ring chronologies have been constructed using data collected from subfossil trees preserved under favourable conditions in lake sediments and peat deposits. Tree-ring widths and densities are commonly used for reconstructions of past climate variability. An alternative way of using these data is to explore the replication curves of these chronologies. Here, we make use of previously collected data that is currently available from tree-ring databases to demonstrate the depositional histories of pine trees once accumulated into the sediment in lake (i.e., riparian trees) and peatland sites. Divergent courses of depositional histories were obtained for different sedimentary settings in southern Finland. Accumulation of peatland pines was high, but that of riparian trees was low around 1.0 ka during the Medieval Climate Anomaly (MCA). By contrast, the accumulation of peatland pines declined towards the Little Ice Age (LIA), while that of riparian trees increased, with a culmination around 0.7 ka. We interpret these variations to mean transitional environmental changes in the corresponding habitats and to indicate increased precipitation and a rising water table from MCA towards the LIA. These results demonstrate the relative roles of recruitment and preservation potentials, and thus of palaeoecological and taphonomic processes, in controlling the tree accumulation in peatland and lake environments, respectively. We conclude that subfossil tree-ring chronologies, even those extracted from electronic databases, can provide important insights into palaeoecology, furnishing new perspectives on palaeoclimate, palaeohydrology of lakes and peatlands, and for studying the tree population responses to past climatic changes.
\end{abstract}

Samuli Helama. Natural Resources Institute Finland, P.O. Box 16, 96301 Rovaniemi, Finland. samuli.helama@luke.fi

Tomi P. Luoto. Division of Aquatic Sciences, Department of Biological and Environmental Science, University of Jyvaskyla, P.O. Box 35, 40014, Finland. tomi.p.luoto@jyu.fi

Liisa Nevalainen. Division of Aquatic Sciences, Department of Biological and Environmental Science, University of Jyvaskyla, P.O. Box 35, 40014, Finland. liisa.e.nevalainen@jyu.fi

Johannes Edvardsson. Quaternary Sciences, Department of Geology, Lund University, Sölvegatan 12, SE22362 Lund, Sweden. johannes.edvardsson@geol.lu.se

Keywords: Palaeobotany; palaeoclimatology; palaeoecology; palaeohydrology; taphonomic gain; tree-ring

Submission: 30 June 2016 Acceptance: 26 December 2016

Helama, Samuli, Luoto, Tomi P., Nevalainen, Liisa, and Edvardsson, Johannes. 2017. Rereading a tree-ring database to illustrate depositional histories of subfossil trees. Palaeontologia Electronica 20.1.2A: 1-12

palaeo-electronica.org/content/2017/1735-depositional-histories

Copyright: January 2017 Palaeontological Association 


\section{INTRODUCTION}

Recent changes in our climate can be evaluated by examining various types of long-term data with environmental indications. Apart from ongoing warming (Jones et al., 2012), the instrumental data exhibit changes in global precipitation patterns with considerable increase in precipitation by $10-40 \%$ in northern Europe in the course of the 20th century (Dore, 2005). An increasing risk of extreme hydroclimate events is predicted in the coming decades in the same region (Räisänen and Joelsson, 2001; Palmer and Räisänen, 2002). Moreover, there is a possibility that the early stage of the growing season may experience more precipitation (Ylhäisi et al., 2010). Uncertainties remain, however, with different aspects of future hydroclimate change (Frei et al., 2006; Räisänen, 2007). Indirect estimates of climate variability (i.e., proxy records) help to increase our understanding of climate variations in a longer-term perspective and to assess the climate models of future climate scenarios (Bradley, 2000; Braconnot et al., 2012). Tree rings provide late Quaternary records of climate variability. These records have high temporal resolution (from annual to even intra-annual) and can have wide spatial coverage over land areas (Fritts, 1976; Hughes, 2011). Tree-ring chronologies of various species can be used to reconstruct drought variability across Europe (Cook et al., 2015). In Fennoscandia, the chronologies of Scots pine (Pinus sylvestris L.) tree rings are sensitive to moisture conditions, particularly during the early stage of the growing season (Jönsson and Nilsson, 2009; Helama and Lindholm, 2003) and have been shown to record summer precipitation variability (Henttonen, 1984; Linderholm and Molin, 2005). The longest of the Scots pine and Norway spruce (Picea abies [L.] H. Karst.) chronologies have been used to reconstruct hydroclimate variability over the last millennium in Fennoscandia (Seftigen et al., 2015) and the chronologies of Scots pine over the past 14 centuries in south-east Finland (Helama et al., 2009; Helama, 2014). Importantly, these records portray the hydroclimate variations through the Medieval Climate Anomaly (MCA; Diaz et al., 2011) and the Little Ice Age (LIA; Matthew and Briffa, 2005), thus placing the instrumental records into a perspective of contrasting past climatic conditions. These intervals are particularly interesting pre-industrial periods with relatively warm (MCA) and cool climates (LIA) over wide areas in Europe (Luterbacher et al., 2016). Compared to temperature histories, the characteristics of the MCA and LIA hydroclimates remain less quantified. Recent dendroclimatic studies have, however, quantified markedly dry MCA (AD 1000$1200)$ over large regions in continental north-central Europe and southern Fennoscandia (ca. $60^{\circ} \mathrm{N}$ to $50^{\circ} \mathrm{N}$ and $5^{\circ} \mathrm{E}$ to $20^{\circ} \mathrm{E}$ ). The magnitude of this drought appears to exceed the hydroclimate variations during the LIA (AD 1550-1750) and instrumental period (Helama et al., 2009; Cook et al., 2015). Additional records are needed to understand the details of these climatic variations and the stress these long-term changes pose for ecosystems.

Previous analyses of droughts and pluvials during the MCA and LIA have been based on networks of long tree-ring chronologies (Helama et al., 2009; Seftigen et al., 2015; Cook et al., 2015). These records result from long-time efforts of constructing composite tree-ring chronologies from subfossil, archaeological, and architectural materials, in addition to updating the long chronologies with modern tree rings. Effective, continuing use of such materials collected and dated in the course of several decades is greatly facilitated by archival of tree-ring datasets into well-organized databases. These archives may be private or publicly distributed (Grissino-Mayer and Fritts, 1997; Läänelaid, 2000; Corona et al., 2010; Jansma et al., 2012), and they make it possible to properly obtain the previously studied tree-ring assemblages for novel investigations, new research targets, upgraded data analyses, and research hypotheses. A treering collection that played an essential role in previous tree-ring based reconstructions of past hydroclimate variations in Europe (Cook et al., 2015) and in Fennoscandia (Helama et al., 2009; Seftigen et al., 2015) initiates from the Tree-Ring Data Bank SAIMA. This is a regionally concentrated database containing different types of tree-ring data from Finland and adjacent areas. With regards to hydroclimate reconstructions, the tree-ring data from this database constitutes a long composite tree-ring chronology of south-east Finland since AD 535 (Helama et al., 2005). Comparisons with the local climatic records have shown that the tree-ring widths of this chronology correlate strongly with the variations in early-summer (May-June) precipitation over the period with instrumental weather observations (Helama and Lindholm, 2003; Helama et al., 2005), the pre-instrumental part of the chronology thus providing palaeoclimatic variations of precipitation history over the late Holocene. Integration of this dendroclimatic proxy data into multi-proxy comparisons with sedimentary midge (Luoto and Helama, 2010), mayfly and caddisfly 
(Luoto et al., 2013), and cladoceran fossil assemblages (Nevalainen et al., 2013) have resulted in palaeoclimatological and palaeolimnological reconstructions indicative of varying climate conditions during the MCA and LIA. During the MCA the summers were likely warm and dry, as contrasted by the snowy winters, in comparison to summers of the LIA that were generally wetter, whereas the winters may have actually been less snowy and undergone shortening of the ice-free season during the LIA (Luoto and Helama, 2010; Luoto et al., 2013; Nevalainen et al., 2013; Luoto and Nevalainen, 2015). The results presented thus far have, therefore, supported the concept of the MCA and LIA. These results also highlight the value of multi-proxy comparisons and emphasize the need for additional well-dated proxy records over the MCA and LIA to be examined for inter- and intraregional and inter-proxy analyses.

Dendroclimatic reconstructions are commonly produced by transforming the annual values of a mean tree-ring chronology (or a network of chronologies) into verifiable estimates of year-toyear climate variability (Fritts, 1976, 1991). Alternatively, the replication curves of tree-ring chronologies can be used to portray temporal variations in depositional histories of the trees comprising the chronologies. Abundant materials of subfossil pines have previously been collected from boreal peatlands (Edvardsson et al., 2012a, 2012b, 2014a, 2014b) and lake sediments (Gunnarson, 2001, 2008; Gunnarson et al., 2003). Such specimens are preserved due to acidic anoxic conditions in their sedimentary environment (Greenwood, 1991) and can be used to illustrate the arboreal depositional histories. Moreover, their replication data can be used to infer past climatic and environmental fluctuations. The colonization of pine to peatland is interpreted in terms of drier surface conditions (Edvardsson, 2013). In lacustrine sites, a rise of lake level drowns the riparian trees that may then accumulate in the sediments (Gunnarson, 2001). Tree-ring chronologies thus provide the Quaternary research with exactly dated palaeobotanical evidence of climate-driven tree population dynamics over the past centuries and millennia (Edvardsson et al., in press). However, a variety of taphonomic processes influence the data due to post-depositional modifications of the fossil assemblages (Wilson, 1988; Martin, 1999); the taphonomic processes ought to be taken into account when interpreting the tree depositional histories from variations in chronology replication (Helama et al., 2010).
In this paper, we hypothesize that the depositional histories of trees once grown under the same late Holocene climate but in different ecological and depositional environments may vary according to factors influencing the tree recruitment, dying-off phases, and taphonomic processes. In order to test this hypothesis, a subset of tree-ring data was extracted from the Tree-Ring Data Bank SAIMA, these data representing both the lake and peatland sites. As the widely accepted standpoint is that the growth dynamics of trees in such habitats is profoundly influenced by annual to long-term hydroclimatic changes (Edvardsson et al., in press), it is also hypothesized that the recorded variations in the corresponding properties of these tree-ring chronologies can be related to late Holocene droughts and pluvials as experienced by the trees during their lifespans. To do so, we exploit subfossil tree-ring width data of Scots pine representing not only distinctly different ecosystems and depositional environments (lake versus peatland), but also contrasting climatic periods of the MCA and LIA. In so doing, we make use of these exactly dated multi-centennial data to investigate the possibility of applying the data of chronology replication as an indicator of ancient tree communities and taphonomic processes and, finally, as integrated proxies of hydroclimate variations through the MCA and LIA. Our study makes an essential contribution for understanding the potential of using the subfossil tree-ring data as palaeoclimatic and palaeoecologic proxies of the Holocene climate transitions.

\section{MATERIAL AND METHODS}

\section{Tree-ring Data}

Tree-ring data were extracted from the TreeRing Data Bank SAIMA (currently positioned at: lustiag.pp.fi/Saima/). The data were also available as a part of The International Tree-Ring Data Bank (Meriläinen and Timonen, 2004). The data used herein represent Scots pine (Pinus sylvestris L.) tree-ring series originating from subfossil samples of trees (i.e., megafossils) preserved in the sediments of lakes and peatlands in the south boreal forests (Ahti et al., 1968) of south-eastern Finland between $62.03^{\circ} \mathrm{N}$ and $61.80^{\circ} \mathrm{N}$ and $29.75^{\circ} \mathrm{E}$ and $28.83^{\circ} \mathrm{E}$ (Table 1; Figure 1). These data consist of eight lake sites and one peatland site with total number of 152023 rings and 939 tree-ring series measured from 590 subfossil tree trunks (Table 1). The number of trees per site varied between 7 and 170 subfossil specimens. However, the mean 
TABLE 1. Characteristics of the eight lake sites (L1-L8) and one peatland site (P9) and their tree-ring data. Abbreviations: LA, Latitude; LO, longitude; NR, the number of rings, NS, the number of tree-ring series; NT, the number of trees; LS, the mean length of the series in years; FY and LA, the first (FY) and last (LY) calendar year (A.D.) of the site chronology; and LC, the total length of the chronology in years.

\begin{tabular}{|c|c|c|c|c|c|c|c|c|c|c|}
\hline Site name & Code & LA & LO & NR & NS & NT & LS & FY & LY & LC \\
\hline Alakieluu Louhi Kerimäki & L1 & 61.93 & 28.98 & 3424 & 21 & 13 & 163 & 1144 & 1705 & 562 \\
\hline Liippilampi Louhi Kerimäki & L2 & 61.92 & 29.03 & 23579 & 158 & 95 & 149 & 595 & 1816 & 1222 \\
\hline Kaivanto Louhi Kerimäki & L3 & 61.93 & 28.98 & 28707 & 160 & 94 & 179 & 535 & 1744 & 1210 \\
\hline Isokortteikko Kerimäki & L4 & 61.97 & 28.87 & 6464 & 36 & 19 & 180 & 844 & 1693 & 850 \\
\hline Valkeajarvi Makkola Kerimäki & L5 & 61.97 & 28.87 & 26703 & 150 & 78 & 178 & 582 & 1742 & 1161 \\
\hline Herajärvi Makkola Kerimäki & L6 & 61.97 & 28.83 & 31863 & 214 & 170 & 149 & 559 & 1732 & 1174 \\
\hline Hiisjärvi Kerimäki & L7 & 61.90 & 29.02 & 7251 & 57 & 35 & 127 & 885 & 1698 & 814 \\
\hline Valkiajärvi Riikola Kerimäki & L8 & 62.03 & 29.17 & 2244 & 12 & 7 & 187 & 1233 & 1831 & 599 \\
\hline Purujärvi Suursuo Kesälahti & P9 & 61.80 & 29.75 & 21788 & 131 & 79 & 166 & 845 & 1330 & 486 \\
\hline
\end{tabular}

length of the series did not exhibit marked differences between the sites being an average 164 years, with longest and shortest mean lengths of 187 and 127 years, respectively. These data are provided in the database as readily cross-dated

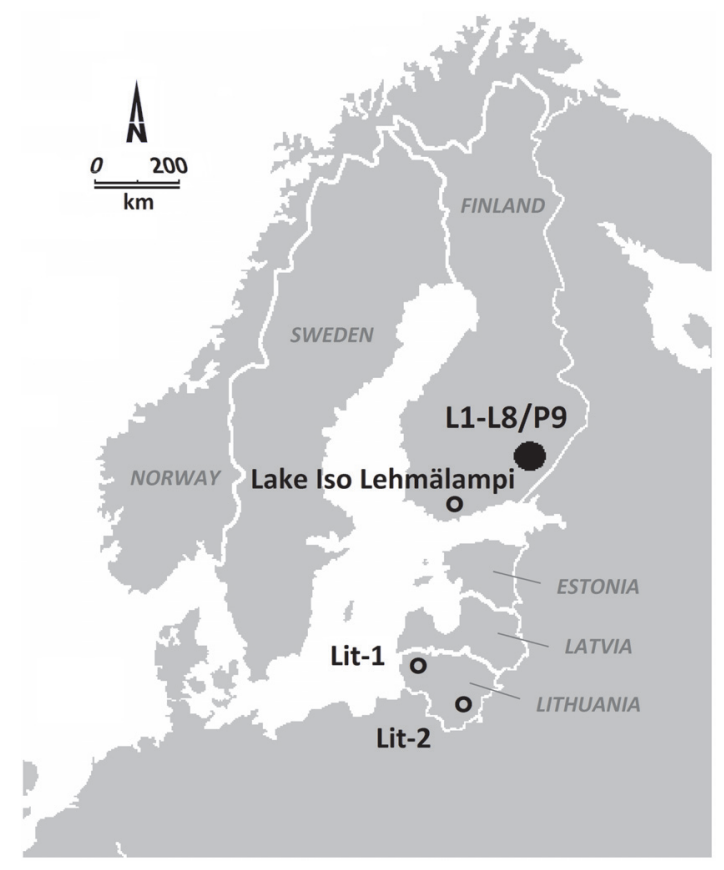

FIGURE 1. Map of North Europe showing the locations of the study site in southern Finland (filled circle) and other late Quaternary palaeoclimate-data producing sites (open circles) mentioned in this study. Lake Iso Lehmälampi is the site of water level reconstructions based on subfossils of the chironomid midge and cladoceran water flea (Luoto, 2009; Nevalainen et al., 2011; Nevalainen and Luoto, 2012). Lit-1 and Lit-2 are tree-ring sites studied by Pukienè (1997) and Edvardsson et al. (2016), respectively. using standard procedures (Fritts, 1976; Schweingruber, 1988), that is, each tree-ring value is assigned to calendar year. Dating recheck of treering measurements was carried out using Cofecha software (Holmes, 1983; Holmes et al., 1986; Grissino-Mayer, 2001).

In general, the processes involving the megafossil deposition are characterised by autochthonous burial. Because of their large size, tree trunks remain minimally transported, especially in peatland sites. In lacustrine conditions, however, a fallen trunk may become captured by lake ice during the boreal winter and transported from the shore. Such minimally transported specimens would, strictly speaking, represent parautochthonous (sensu Kidwell et al., 1986) plant material. Plant remains are preserved in these environments because of gradual accumulation rates (Greenwood, 1991) and reduced rates of biological and mechanical degradation. These circumstances benefit the preservation of whole or nearly complete plants (Wing, 1988; Rich, 1989), such as megafossils. Analysis of our data to illustrate the pine population dynamics followed previous analyses (Edvardsson et al., in press). The depositional histories of tree accumulation were obtained as the replication curves of each site chronology demonstrating the number of tree-ring series (i.e., the number of trees) per calendar year. Temporal fluctuations in the replication curves were plotted to depict the periods when the availability of subfossil tree trunks in a given site was either increased or decreased. These fluctuations were compared amongst the lake sites and between the lake and peatland sites, as well as with other proxy data indicative of variations in past climatic conditions and water table levels. 


\section{Drought Index}

Previously, a set of annual maps of reconstructed summer wetness and dryness in Europe had been developed as the "Old World Drought Atlas" over the Common Era (Cook et al., 2015). These maps are based on dendroclimatic reconstructions of self-calibrating Palmer Drought Severity Index (PDSI) (van der Schrier et al., 2013) on a 5414-point half-degree longitude by- latitude grid calculated over the three summer months (June through August). This PDSI data thus reflects spring-summer soil moisture conditions (Cook et al., 2015). Here we used a spatially restricted portion $\left(65^{\circ} \mathrm{N}\right.$ to $60^{\circ} \mathrm{N}$ and $25^{\circ} \mathrm{E}$ to $30^{\circ} \mathrm{E}$ ) of this large dataset for comparison with our pine data. To illustrate long-term hydroclimatic variations, this PDSI series was smoothed using 150-year spline function (Cook and Peters, 1981). This smoothed record was expected to portray low-frequency climate variability, i.e. variability on centennial and longer scales. Being possibly the most widely used regional index of drought, the PDSI is indicative not only of the drought intensity (i.e., negative index) but also the beginning and ending dates of corresponding events (Alley, 1984). High coherence between this drought (PDSI) and the precipitation indices implies that the former is driven mainly by precipitation variability. Yet, the PDSI is additionally dependent on antecedent soil and atmospheric conditions, which both contribute to a current month's drought index (Guttman, 1998).

\section{Palaeolimnological Reconstructions}

Several palaeolimnological studies have recently concentrated on Lake Iso Lehmälampi (Luoto, 2009; Nevalainen et al., 2011; Nevalainen and Luoto, 2012) situated in southern Finland $\left(60.33^{\circ} \mathrm{N} ; 24.60^{\circ} \mathrm{E}\right)$. This site may represent an ideal comparison with tree-ring chronologies for several reasons. The palaeolimnological records from Lake Iso Lehmälampi have been shown to contain the sedimentary midge (Chironomidae) and water flea (Cladocera) assemblages indicative of water level fluctuations during the MCA and LIA. Moreover, the past water-level variations have been quantitatively reconstructed for this site using the microfossil remains of both chironomids and Cladocera by applying the transfer function approach (calibration-in-space). In addition, the Cladocera-calibrations drawn from (1) intra-site and (2) multi-site training sets have resulted in two alternative reconstructions of past water-level variations. Depositional histories of our lake and peatland sites were compared to these three types of reconstructions from the same site (Lake Iso Lehmälampi) to reveal any possible difference the proxy type (chironomids versus Cladocera) or the type of calibration (intra-site versus multi-site training set) may have produced for the observed variations.

\section{RESULTS}

\section{Replication Curves}

Tree-ring chronologies of lake and peatland sites represent late Holocene pine populations between AD 535 and 1831 (Table 1). Temporal distribution of the chronologies showed synchronous depositional histories of subfossil trees among the lake sites (Figure 2.1). Accumulation of the trees started to increase towards the late ninth century, with a subsequent minimum during the first half of the twelfth century. A peak in accumulation was evident towards the late thirteenth century, around $A D$ 1300. Thereafter, the accumulation rate decreased with only slight increase in subfossil availability during the first half of the sixteenth century. This course of depositional histories was notably similar for virtually all of the lake sites, with only slight differences discernible between the corresponding replication curves.

Accumulation of subfossil trees in the peatland site showed a distinctly divergent course of depositional history (Figure 2.2). Since the beginning of the accumulation in the ninth century, the replication curve peaked more sharply at the turn of the millennium, ca. AD 1000. Thereafter, a decrease in the accumulation of trees was a notable feature of the replication curve; the most recent subfossil pine specimen was dated as the early fourteenth century. Whereas the accumulation of the trees increased in lake sites over the twelfth and thirteenth centuries, the peatland site indicated no similar increase. Compared to peatland chronology, all of the lake site chronologies exhibit more continuous deposition of subfossil trunks, with extended temporal coverage (Table 1). The length of the peatland chronology (486 years) is notably exceeded by the mean length of chronologies from lake sites (949 years).

\section{Reconstructed Droughts and Pluvials}

Comparison with the long-term variations in reconstructed Palmer Drought Severity Index (PDSI) showed clear consistency with the depositional history of the peatland pines. Accumulation of peatland pines started when the PDSI values declined during the ninth century, indicating 


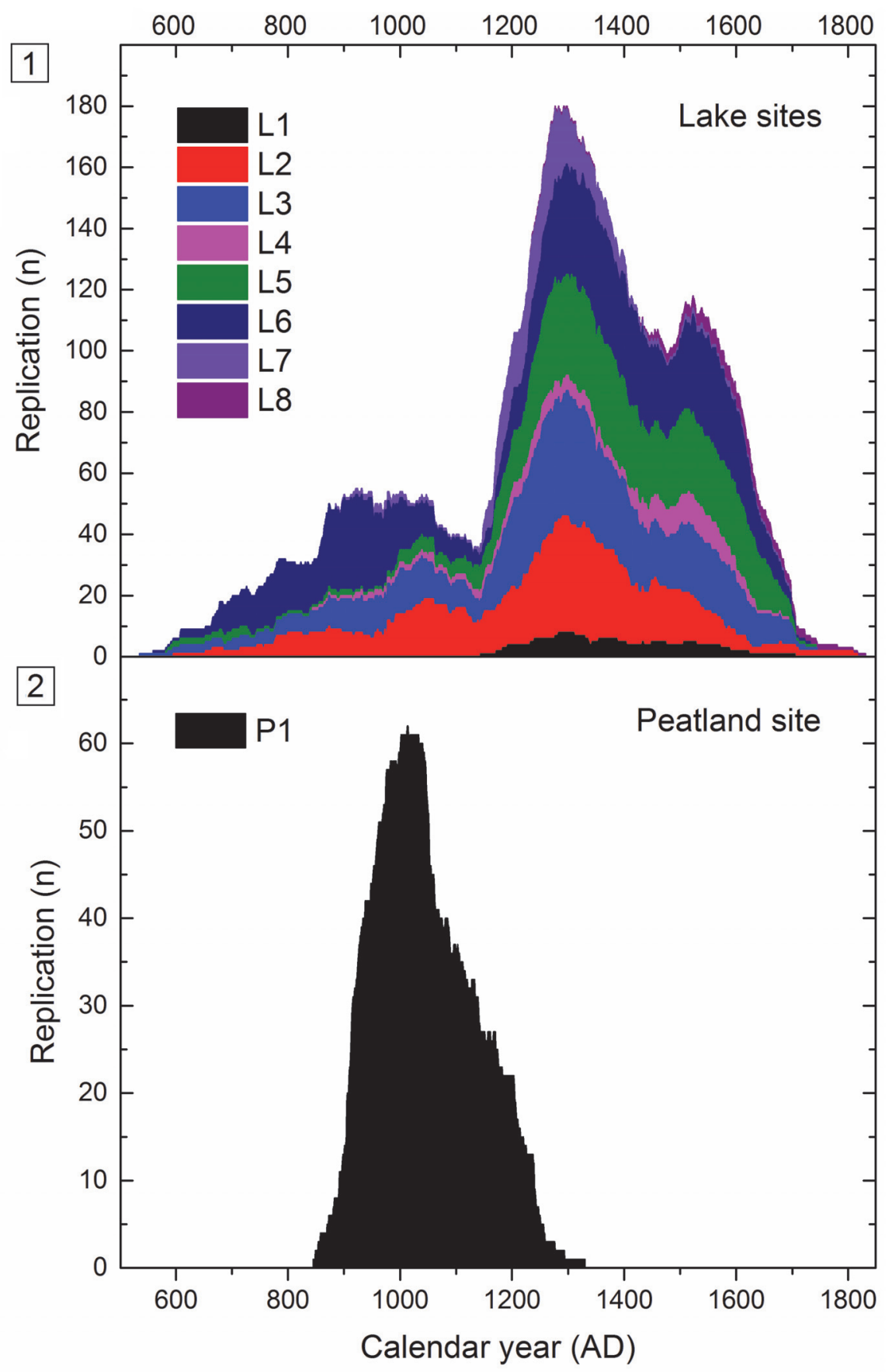

FIGURE 2. Replication curves of the subfossil tree-ring chronologies. 1, lake sites; and 2, the peatland site. Data are given in Table 1.

increasing drought in the region (Figure 3.1). The peak in accumulation around c.a. AD 1000 is consistent with the long-term drought as illustrated by negative PDSI values between $A D$ 880s and 1080s. Increasing moisture, as observed by the PDSI thereafter, coincides with decreasing replication of peatland pines. On the other hand, this increase in moisture corresponds with increasing replication in the lake site chronologies, especially from the 1200s onwards. Moreover, the subsequent minimum in the lake sites' replication during the first half of the twelfth century coincides with low PDSI values over the same period. Likewise, the minor phase of increase during the first half of the sixteenth century occurred during the rising PDSI values. 


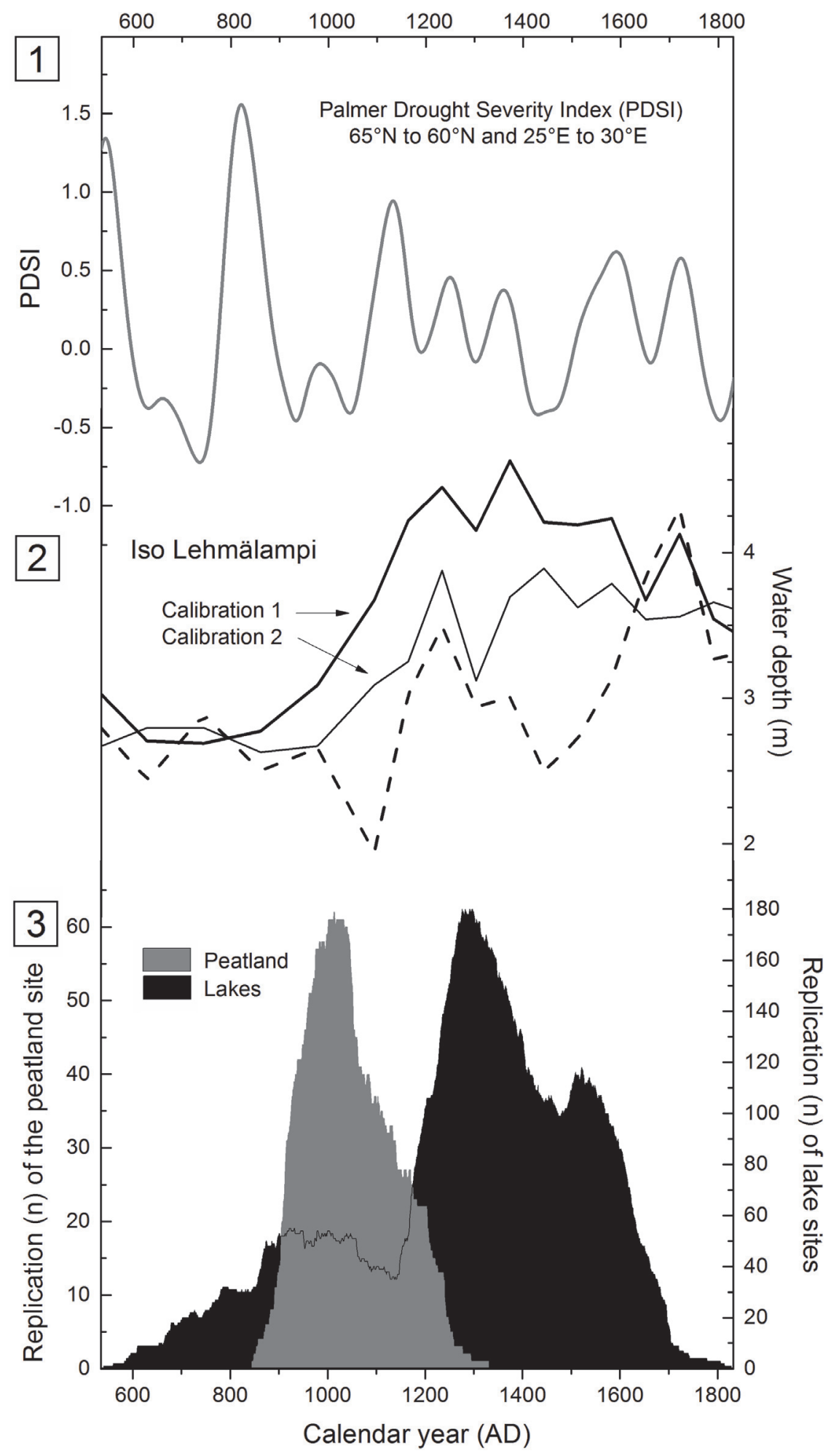

FIGURE 3. Comparisons of the proxy indications from southern Finland from $A D 600$ to 1800. 1, the Palmer Drought Severity Index (PDSI) reflecting spring-summer soil moisture conditions (Cook et al., 2015); 2 , the water level reconstruction based on subfossil chironomid midge (dashed line) and cladoceran water flea (solid lines; calibrations from intra-site by thick line and multi-site training sets by thin line) communities in Lake Iso Lehmälampi (Luoto, 2009; Nevalainen et al., 2011; Nevalainen and Luoto, 2012); and 3, the replication curves of the subfossil tree-ring chronologies constituting a peatland and eight lake sites (this study). 
Comparison with the palaeolimnological reconstructions from chironomids and cladoceran evidence for water level fluctuations in Lake Iso Lehmälampi confirmed the patterns of increased peatland pine accumulation during the droughts and decreased accumulation in the same environment during the pluvials (Figure 3.2). All three reconstructions of late Holocene water depth variations in Lake Iso Lehmälampi showed a generally lowered water table during the late part of the first millennium $A D$. This phase coincided with the period of tree accumulation in the peatland site. Thereafter, all three reconstructions indicated rising water tables not later than the twelfth century. Timing of this change in palaeohydrology was markedly consistent with the increasing accumulation of trees in the lake sites (Figure 3.3). More details of this linkage are observed when comparing the tree accumulation with chironomid-based reconstruction (dotted line in Figure 3.2). This comparison indicates a coinciding minimum in both records during the eleventh and fifteenth centuries, consistently with low PDSI values.

\section{DISCUSSION}

Peatland pine accumulation increased during the drought around AD 1000, consistent with the PDSI reconstruction. This increase, therefore, occurred during a phase of dry surface conditions beneficial for pine colonization (Torbenson et al., 2015; Edvardsson et al., in press). Recent forestry experiments have demonstrated that peatland drainage is followed by increased pine recruitment, stand density, and mean tree size (Sarkkola et al., 2004). In peatland sites any decrease in soil moisture is directly encountered by the root system of trees growing on the site. With these regards the physical and chemical changes within the uppermost $30 \mathrm{~cm}$ of peat soil appear to play an essential role in determining the changing soil-plant interactions (Paavilainen, 1966; Boggie, 1972). In the context of the past droughts, it can be deduced that the water table level may have dropped in proportion to this depth.

Since AD 1000 the replication of peatland pines declined and that of lake sites increased, with a concomitant indication of increased water supply. Raising lake water level, indicated by chironomid- and cladoceran-based reconstructions, likely submerged the trees recruited near the lake shores during the period of low lake water level. In the peatland site, however, surfaces became excessively wet and did not allow pine regeneration in that environment. Rising lake water level contributed to necrological processes by inciting riparian tree mortality and by increasing the preservation potential of trees transported into the potentially anoxic depositional environment. The recruitment could likely continue adjacent to the riparian zone, whereas pine recruitment may have been largely halted by unsuitably high water level, especially on peatland areas with flat topography. This viewpoint concurs with that of differing plant accumulation processes in lake and peatland sites (Greenwood, 1991) and effectively explains the contrasting trends in the two replication curves. Generally moist conditions over this period of higher water levels are also inferred from the PDSI reconstruction with no similar droughts during the following centuries, in comparison to that observed at the turn of the millennium.

Once the high lake level was attained, the accumulation of riparian trees was not increasing. Instead, the replication of chronologies from lake sites demonstrates a gradual decline in subfossil availability since around AD 1300 . Likely, it is not the high lake level itself, but its progressive rise that increased the accumulation in that environment. These palaeohydrological indications appear consistent with the long-term climatic evolution of continental Europe and Fennoscandia with evidence for wide-spread megadroughts between $A D$ 1000 and 1200 (Cook et al., 2015). Reconstructed by multiple proxies for southern Finland, these fluctuations represent summertime droughts during the Medieval Climate Anomaly (MCA) and increased moisture during the following centuries characteristic of the Little Ice Age (LIA) conditions (Luoto and Helama, 2010; Luoto et al., 2013; Nevalainen et al., 2013; Luoto and Nevalainen, 2015). This depiction would demonstrate why the lake and peatland sites can be so deviant in accumulation rates of the same plant part and under the same climatic fluctuations, the marked alterations originating from the prevailing processes of necrology and biostratinomy (Gastaldo, 1988).

To explain these variations in peatland and lake sites, especially their dissimilarities, we further suggest reading the rapid changes in the replication curves as indications of a transitional environmental change. To this end, we infer that riparian pines once recruited during the MCA were submerged by progressively rising water levels and deposited into the lacustrine sediment. Such development would cause a positive trend in the lake sites' replication curve, whereas the recruitment of peatland pines was simultaneously impaired by gradual elevation of water table level, hence the 
coinciding negative trend in peatland site's replication. Thus, decreasing potential for recruitment in the peatland site would coincide with increasing potential for preservation in lake sites. This interpretation demonstrates the respective roles of palaeoecologic and taphonomic processes in forming the replication curves of peatland and lake chronologies. Yet, the depositional histories in both sedimentary environments contain palaeohydrological signals of their own. These implications show the importance of observing lacustrine plant fossils from taphonomic perspective (Rich, 1989). The taphonomic evidence for the lake site accumulation can be thought of as a representation of taphonomic gain (Wilson, 1988), demonstrating the ways the taphonomic agents not only degrade the details of palaeontological information, but also contribute to palaeoenvironmental reconstruction by leaving characteristic evidence of taphonomic process in the record.

Although the reconstructed PDSI and lake level fluctuations largely explained the main characteristics in the depositional histories, it cannot be ruled out that additional factors may also have played a role in determining the obtained replication records. Drying of the peatland site likely resulted in increased pine recruitment, stand density, and mean tree size (Sarkkola et al., 2004). The concomitant increase in tree stand growth may, in turn, have further lowered the water table level within the site, because of increasing evapotranspiration (Hökkä et al., 2008). Such relationships could intensify the climatic effects of the MCA drought, to create conditions beneficial for pine colonization. Moreover, the pine recruitment depends on seed crop, known to improve with increasing site fertility (Sarvas, 1962). The pine seed crop also depends on summer warmth, especially in subarctic sites (Henttonen et al., 1986). Under such circumstances the replication curves of subfossil tree-ring chronologies are in fact expected to reflect summer temperature variability (Helama et al., 2005, 2010). Whereas the temperature control on seed maturation weakens towards the south (Henttonen et al., 1986), past temperature variations can be expected to have only minor influence on our replication records. Nonetheless, the early MCA was characterized by rising temperature levels in most of Europe (Luterbacher et al., 2016) and also in the study region (Helama et al., 2014). If the pine seed crop increased during the early MCA as the growing conditions changed, this may have induced the ninth century increase observed not only in the peatland pine curve, but also, albeit less prominently, in the lake sites' data.

In a larger regional view, our tree-ring chronology of peatland pines can be compared with those previously established in Lithuania (Pukienè, 1997, 2001; Edvardsson et al., 2016) (see Figure 1). Overlapping with our data, the radiocarbon dated pine chronology from a Lithuanian site Užpelkių Tyrelis (Pukienè, 1997) spanned approximately AD 951-1148, thus coinciding markedly with the maximum phase of peatland pines in Finland. The synchrony of these events suggests a common climatic forcing causing the pine colonization on the two distant sites. Moreover, the coincidence of these recruitment phases with the MCA implies that they may have been induced by the relatively dry climates prevailing over a larger portion of continental north-central Europe and southern Fennoscandia, prevailing over the Lithuanian and Finnish sites, between AD 1000 and 1200 (Cook et al., 2015).

However, the other radiocarbon-dated chronologies from Lithuania span approximately AD 636-956 (Edvardsson et al., 2016), AD 551837, AD 1143-1474, and AD 1773-1924 (Pukienè, 1997 ), and thus with no meaningful overlaps with the Finnish peatland pine chronology. These discrepancies may imply spatially restricted responses in hydrological cycle, peatland vegetation, or both, to climatic shifts of continental scale. In addition, the northern location of the Finnish site has possibly made the trees more sensitive to temperature variability in comparison to the Lithuanian sites, which at present show tree-growth response associated to a mixture of pre-growth season temperature and long-term hydrological changes (Edvardsson et al., 2015). We concur with the previously set target for developing continuous annually resolved moisture-sensitive tree-ring records for the same region (Edvardsson et al., 2016). Extending these chronologies will detail the picture of hydroclimate anomalies over the Holocene. They will also enable assessments of climate model simulations and future climate scenarios.

\section{ACKNOWLEDGMENTS}

This article has benefited from the comments of two anonymous referees. The manuscript was written while the first author was supported by Grant 288267 from the Academy of Finland. 


\section{REFERENCES}

Ahti, T., Hämet-Ahti, L., and Jalas, J. 1968. Vegetation zones and their sections in northwestern Europe. Annales Botanici Fennici, 3:169-211.

Alley, W.M. 1984. The Palmer Drought Severity Index: Limitations and assumptions. Journal of Climate and Applied Meteorology, 23:1100-1109.

Boggie, R. 1972. Effect of water-table height on root development of Pinus contorta on deep peat in Scotland. Oikos, 23:304-312.

Braconnot, P., Harrison, S.P., Kageyama, M., Bartlein, P.J., Masson-Delmotte, V., Abe-Ouchi, A., OttoBliesner, B., and Zhao, Y. 2012. Evaluation of climate models using palaeoclimatic data. Nature Climate Change, 2:417-424.

Bradley, R.S. 2000. Past global changes and their significance for the future. Quaternary Science Reviews, 19:391-402.

Cook, E.R. and Peters, K. 1981. The smoothing spline: A new approach to standardizing forest interior treering width series for dendroclimatic studies. TreeRing Bulletin, 41:45-53.

Cook, E.R., Seager, R., Kushnir, Y., Briffa, K.R., Büntgen, U., Frank, D., Krusic, P.J., Tegel, W., van der Schrier, G., Andreu-Hayles, L., Baillie, M., Baittinger, C., Bleicher, N., Bonde, N., Brown, D., Carrer, M., Cooper, R., Čufar, K., Dittmar, C., Esper, J., Griggs, C., Gunnarson, B., Günther, B., Gutierrez, E., Haneca, K., Helama, S., Herzig, F., Heussner, K.-U., Hofmann, J., Janda, P., Kontic, R., Köse, N., Kyncl, T., Levanič, T., Linderholm, H., Manning, S., Melvin, T.M., Miles, D., Neuwirth, B., Nicolussi, K., Nola, P., Panayotov, M., Popa, I., Rothe, A., Seftigen, K., Seim, A., Svarva, H., Svoboda, M., Thun, T., Timonen, M., Touchan, R., Trotsiuk, V., Trouet, V., Walder, F., Ważny, T., Wilson, R., and Zang, C. 2015. Old World megadroughts and pluvials during the Common Era. Science Advances, 1:e1500561. doi: 10.1126/sciadv.1500561

Corona, C., Guiot, J., Edouard, J.L., Chalié, F., Büntgen, U., Nola, P., and Urbinati, C. 2010. Millennium-long summer temperature variations in the European Alps as reconstructed from tree rings. Climate of the Past, 6:379-400.

Diaz, H.F., Trigo, R., Hughes, M.K., Mann, M.E., Xoplaki, E., and Barriopedro, D. 2011. Spatial and temporal characteristics of climate in medieval times revisited. Bulletin of the American Meteorological Society, 92:1487-1500.

Dore, M.H.I. 2005. Climate change and changes in global precipitation patterns: what do we know? Environment International, 31:1167-1181.

Edvardsson, J. 2013. Holocene climate change and peatland dynamics in southern Sweden based on tree-ring analysis of subfossil wood from peat deposits. Lundqua Thesis, 68:1-40.

Edvardsson, J., Corona, C., Mažeika, J., Pukienè, R., and Stoffel, M. 2016. Recent advances in long-term climate and moisture reconstructions from the Baltic region: Exploring the potential for a new multimillennial tree-ring chronology. Quaternary Science Reviews, 131:118-126.

Edvardsson, J., Edwards, T.W.D., Linderson, H., and Hammarlund, D. 2014a. Climate forcing of growth depression in subfossil South Swedish bog pines inferred from stable isotopes. Dendrochronologia, 32:55-61.

Edvardsson, J., Leuschner, H.H., Linderson, H., Linderholm, H.W., and Hammarlund, D., 2012a. South Swedish bog pines as indicators of Mid-Holocene climate variability. Dendrochronologia, 30:93-103.

Edvardsson, J., Linderson, H., Rundgren, M., and Hammarlund, D. 2012b. Holocene peatland development and hydrological variability inferred from bog-pine dendrochronology and peat stratigraphy - a case study from southern Sweden. Journal of Quaternary Science, 27:553-563.

Edvardsson, J., Poska, A., Van der Putten, N., Rundgren, M., Linderson, H., and Hammarlund, D. 2014b. Late-Holocene expansion of a South Swedish peatland and its impact on marginal ecosystems: evidence from dendrochronology, peat stratigraphy and palaeobotanical data. The Holocene, 24:466-476.

Edvardsson, J., Rimkus, E., Corona, C., Šimanauskiene, R., Kažys, J., and Stoffel, M. 2015. Exploring the impact of regional climate and local hydrology on Pinus sylvestris L. growth variability - A comparison between pine populations growing on peat soils and mineral soils in Lithuania. Plant and Soil, 392:345356.

Edvardsson, J.G., Stoffel, M., Corona, C., Bragazza, L., Leuschner, H.H., Charman, D.J., and Helama, S. In press. Subfossil peatland trees as proxies for Holocene palaeohydrology and palaeoclimate. Earth-Science Reviews.

Frei, C., Schöll, R., Fukutome, S., Schmidli, J., and Vidale, P.L. 2006. Future change of precipitation extremes in Europe: intercomparison of scenarios from regional climate models. Journal of Geophysical Research, 111:D6. doi: 10.1029/2005JD005965

Fritts, H.C. 1976. Tree Rings and Climate. Academic Press, New York.

Fritts, H.C. 1991. Reconstructing Large-scale Climatic Patterns from Tree-ring Data. The University of Arizona Press, Tucson.

Gastaldo, R.A. 1988. Conspectus of phytotaphonomy. The Paleontological Society Special Publication, 3:14-28.

Greenwood, D.R. 1991. The taphonomy of plant macrofossils. p. 141-169. In Donovan, S.K. (ed.), The Processes of Fossilization. Belhaven, London.

Grissino-Mayer, H.D. 2001. Evaluating crossdating accuracy: A manual and tutorial for the computer program COFECHA. Tree-Ring Research, 57:205-221.

Grissino-Mayer, H. and Fritts, H.C. 1997. The International Tree-Ring Data Bank: an enhanced global database serving the global scientific community. The Holocene, 7:235-238. 
Gunnarson, B.E. 2001. Lake level changes indicated by dendrochronology on subfossil pine, Jämtland, central Scandinavian mountains, Sweden. Arctic, Antarctic and Alpine Research, 33:274-281.

Gunnarson, B.E. 2008. Temporal distribution pattern of subfossil pines in central Sweden: perspective on Holocene humidity fluctuations. The Holocene, 18: 569-577.

Gunnarson, B.E., Borgmark, A., and Wastegård, S. 2003. Holocene humidity fluctuations in Sweden inferred from dendrochronology and peat stratigraphy. Boreas, 32:347-360.

Guttman, N.B. 1998. Comparing the Palmer Drought Index and the Standardized Precipitation Index. Journal of the American Water Resources Association, 34:113-121.

Helama, S. 2014. The Viking age as a period of contrasting climatic trends, p. 117-130. In Ahola, J., Frog, and Tolley, C. (eds.), Fibula, Fabula, Fact. Defining and Contextualizing the Viking Age in Finland. Finnish Literature Society, Vantaa, Finland.

Helama, S., Eronen, M., and Timonen, M. 2010. Dendroécologie des bois fossiles dans le nord de la Laponie, p. 709-730. In Payette, S. and Filion, L. (eds.), La Dendroécologie: Principes, méthodes et applications. Presses de l'Université Laval, Québec, Québec.

Helama, S. and Lindholm, M. 2003. Droughts and rainfall in south-eastern Finland since AD 874, inferred from Scots pine ring-widths. Boreal Environmental Research, 8:171-183.

Helama, S., Lindholm, M., Timonen, M., and Eronen, M. 2005. Mid- and late Holocene tree population density changes in northern Fennoscandia derived by a new method using megafossil pines and their tree-ring series. Journal of Quaternary Science, 20:567-575.

Helama, S., Meriläinen, J., and Tuomenvirta, H. 2009. Multicentennial megadrought in northern Europe coincided with a global EI Niño-Southern Oscillation drought pattern during the Medieval Climate Anomaly. Geology, 37:175-178.

Helama, S., Vartiainen, M., Holopainen, J., Mäkelä, H.M., Kolström, T., and Meriläinen, J. 2014. A palaeotemperature record for the Finnish Lakeland based on microdensitometric variations in tree rings. Geochronometria, 41:265-277.

Henttonen, H. 1984. The dependence of annual ring indices on climatic factors. Acta Forestalia Fennica, 186:1-38.

Henttonen, H., Kanninen, M., Nygren, M., and Ojansuu, R. 1986. The maturation of Pinus sylvestris seeds in relation to temperature climate in northern Finland. Scandinavian Journal of Forest Research, 1:243249.

Hökkä, H., Repola, J., and Laine, J. 2008. Quantifying the interrelationship between tree stand growth rate and water table level in drained peatland sites within Central Finland. Canadian Journal of Forest Research, 38:1775-1783.
Holmes, R.L. 1983. Computer-assisted quality control in tree-ring dating and measurement. Tree-Ring Bulletin, 43:69-75.

Holmes, R.L., Adams, R.K., and Fritts, H.C. 1986. Treering Chronologies of Western North America: California, Eastern Oregon and Northern Great Basin with Procedures Used in the Chronology Development Work Including User Manuals for Computer Programs COFECHA and ARSTAN. Laboratory of TreeRing Research, University of Arizona, Tucson.

Hughes, M.K. 2011. Dendroclimatology in high-resolution paleoclimatology, p. 17-34. In Hughes, M.K., Swetnam, T.W., and Diaz, H.F. (eds.), Dendroclimatology, Progress and Prospects. Springer, Dordrecht.

Jansma, E., van Lanen, R.J., Sturgeon, K., Mohlke, S., and Brewer, P.W. 2012. TRiDaBASE: A stand-alone database for storage, analysis and exchange of dendrochronological metadata. Dendrochronologia, 30:209-211.

Jones, P.D., Lister, D.H., Osborn, T.J., Harpham, C., Salmon, M., and Morice, C.P. 2012. Hemispheric and large-scale land-surface air temperature variations: An extensive revision and an update to 2010. Journal of Geophysical Research, 117:D5. doi:10.1029/ 2011JD017139

Jönsson, K. and Nilsson, C. 2009. Scots pine (Pinus sylvestris L.) on Shingle Fields: A dendrochronologic reconstruction of early summer precipitation in mideast Sweden. Journal of Climate, 22:4710-4722.

Kidwell, S.M., Fürsich, F.T., and Aigner, T. 1986. Conseptual framework for the analysis and classification of fossil concentrations. Palaios, 1:228-238.

Läänelaid, A. 2000. Tree ring data from Estonia collected in 1999. University of Joensuu. Faculty of Forestry. Research Notes, 108:107-117.

Linderholm, H.W. and Molin, T. 2005. Early nineteenth century drought in east central Sweden inferred from dendrochronological and historical archives. Climate Research, 29:63-72.

Luoto, T.P. 2009. A Finnish chironomid- and chaoboridbased inference model for reconstructing past lake levels. Quaternary Science Reviews, 28:1481-1489.

Luoto, T.P. and Helama, S. 2010. Palaeoclimatological and palaeolimnological records from fossil midges and tree-rings: the role of the North Atlantic Oscillation in eastern Finland through the Medieval Climate Anomaly and Little Ice Age. Quaternary Science Reviews, 29:2411-2423.

Luoto, T.P., Helama, S., and Nevalainen, L. 2013. Stream flow intensity of the Saavanjoki River, eastern Finland, during the past 1500 years reflected by mayfly and caddisfly mandibles in adjacent lake sediments. Journal of Hydrology, 476:147-153.

Luoto, T.P. and Nevalainen, L. 2015. Late Holocene precipitation and temperature changes in Northern Europe linked with North Atlantic forcing. Climate Research, 66:37-48.

Luterbacher, J., Werner, J.P., Smerdon, J.E., FernándezDonado, L., Gonzalez-Rouco, F.J., Barriopedro, D., 
Ljungqvist, F.C., Büntgen, U., Zorita, E., Wagner, S., Esper, J., McCarroll, D., Toreti, A., Frank, D., Jungclaus, J.H., Barriendos, M., Bertolin, C., Bothe, O., Brázdil, R., Camuffo, D., Dobrovolný, P., Gagen, M., García-Bustamante, E., Ge, Q., Gómez-Navarro, J.J., Guiot, J., Hao, Z., Hegerl, G.C., Holmgren, K., Klimenko, V.V., Martín-Chivelet, J., Pfister, C., Roberts, N., Schindler, A., Schurer, A., Solomina, O., von Gunten, L., Wahl, E., Wanner, H., Wetter, O., Xoplaki, E., Yuan, N., Zanchettin, D., Zhang, H., and Zerefos, C. 2016. European summer temperatures since Roman times. Environmental Research Letters, 11:024001. doi:10.1088/1748-9326/11/2/024001

Martin, R.E. 1999. Taphonomy: a process approach. Cambridge Paleobiology Series, 4:1-508.

Matthews, J.A. and Briffa, K.R. 2005. The 'Little Ice Age': Re-evaluation of an evolving concept. Geografiska Annaler, 87A:17-36.

Meriläinen, J. and Timonen, M. 2004. Tree-Ring Data Bank of Saima Centre for Environmental Sciences in Savonlinna, University of Joensuu, Joensuu (closed down in 2007).

Nevalainen, L., Helama, S., and Luoto, T. 2013. Hydroclimatic variations over the last millennium in eastern Finland disentangled by fossil Cladocera. Palaeogeography, Palaeoclimatology, Palaeoecology, 378:1312.

Nevalainen, L. and Luoto, T.P. 2012. Intralake training set of fossil Cladocera for paleohydrological inferences: evidence for multicentennial drought during the Medieval Climate Anomaly. Ecohydrology, 5:834840.

Nevalainen, L., Sarmaja-Korjonen, K., and Luoto, T.P. 2011. Sedimentary Cladocera as indicators of past water-level changes in shallow northern lakes. Quaternary Research, 75:430-437.

Paavilainen, E. 1966. On the effect of drainage on root system of Scots pine on peat soils. Communicationes Instituti Forestalis Fenniae, 61(1):1-110.

Palmer, T.N. and Räisänen, J. 2002. Quantifying the risk of extreme seasonal precipitation events in a changing climate. Nature, 415:512-514.

Pukienè, R. 1997. Pinewood Growth Dynamics in Užpelkių Tyrelis Oligotrophic Bog during the Subatlantic Period. Summary of Doctoral Dissertation, Institute of Botany and Vilnius University, Vilnius, Lithuania.
Pukienè, R. 2001. Natural changes in bog vegetation reconstructed by sub-fossil tree remnant analysis. Biologija, 2:111-113.

Räisänen, J. 2007. How reliable are climate models? Tellus, 59A:2-29.

Räisänen, J. and Joelsson, R. 2001. Changes in average and extreme precipitation in two regional climate model experiments. Tellus, 53A:547-566.

Rich, F.J. 1989. A review of the taphonomy of plant remains in lacustrine sediments. Review of Palaeobotany and Palynology, 58:33-46.

Sarkkola, S., Hökkä, H., and Penttilä, T. 2004. Natural development of stand structure in peatland Scots pine following drainage: results based on long-term monitoring of permanent sample plots. Silva Fennica, 38:405-412.

Sarvas, R. 1962. Investigations on the flowering and seed crop of Pinus sylvestris. Communicationes Instituti Forestalis Fenniae 53(4):1-198.

Schweingruber, F.H. 1988. Tree Rings. Basics and Applications of Dendrochronology. Kluwer Academic Publishers, Dordrecht.

Seftigen, K., Björklund, J., Cook, E.R., and Linderholm, H.W. 2015. A tree-ring field reconstruction of Fennoscandian summer hydroclimate variability for the last millennium. Climate Dynamics, 44:3141-3154.

Torbenson, M.C.A., Plunkett, G., Brown, D.M., Pilcher, J.R., and Leuschner, H.H. 2015. Asynchrony in key Holocene chronologies: Evidence from Irish bog pines. Geology, 43:799-802.

van der Schrier, G., Barichivich, J., Briffa, K.R., and Jones, P.D. 2013. A scPDSI-based global data set of dry and wet spells for 1901-2009. Journal of Geophysical Research, 118:4025-4048.

Wilson, M.V.H. 1988. Taphonomic processes: information loss and information gain. Geoscience Canada, 15:131-148.

Wing, S.L. 1988. Depositional environments of plant bearing sediments. The Paleontological Society Special Publication, 3:1-13.

Ylhäisi, J.S., Tietäväinen, H., Peltonen-Sainio, P., Venäläinen, A., Eklund, J., Räisänen, J., and Jylhä, K. 2010. Growing season precipitation in Finland under recent and projected climate. Natural Hazards and Earth System Sciences, 10:1563-1574. 